\title{
Conjoined twins, a rare and challenging congenital malformation: a case report.
}

\author{
Aparna Khan ${ }^{1}$, Pradip Kumar Banerjee ${ }^{2}$, Arindam Ghosh ${ }^{3}$ \\ ${ }^{l}$ Associate Professor, Department of Obstetrics and Gynaecology,Burdwan Medical College, West Bengal, \\ India \\ ${ }^{2}$ Professor, Department of Obstetrics and Gynaecology,Burdwan Medical College, West Bengal, India \\ ${ }^{3}$ Junior Resident, Department of Obstetrics and Gynaecology,Burdwan Medical College, West Bengal, India
}

\begin{abstract}
The conjoined twins are a rare and challenging congenital anomaly not only from treatment point of view but also from diagnostic point of view. A 32 year old woman $G_{2} P_{1+o,} L_{1}$ came to labour emergency of Burdwan Medical College Hospital with pain abdomen in a 32 week gestation. She was in early labour. She was diagnosed,at the local chamber by USG, to have conjoined twins. Thoracopagus live female conjoined twins were delivered by caesarean section. The twins died in the nursery next day morning (26/05/13 4.35A.M.)
\end{abstract}

Key Words: conjoined twins, thoracopagus

\section{Case History}

Mrs Mitali Dhara 32 years old $\mathrm{G}_{2} \mathrm{P}_{1+0+0+1}$ residing at a remote village of BURDWAN district of West Bengal, India, attended labor emergency of Burdwan Medical College Hospital, a rural tertiary care centre on 25/05/13 at 8.32A.M with complain of pain abdomen from the night. Her LMP was on 15/10/12, EDD on $22 / 07 / 13$ and period of gestation was 32 weeks. She was diagnosed to have conjoined twins (thoracopagus) by ultrasonography done at 24 weeks of gestation. On examination she had mild pallor, pulse $88 / \mathrm{min}$ regular, blood pressure $110 / 70 \mathrm{~mm}$ of $\mathrm{Hg}$. Uterine size corresponded with 36 gestational week size, one head was palpable at fundal grip and one fetal heart sound was audible at the left spino-umbilical line just below the umbilicus. She was in early labor with fully effaced cervix and $2.5-3 \mathrm{~cm}$ dilated cervical os. Patient was admitted.and advised for emergency LSCS. Before being sent to the OT blood was drawn for $\mathrm{Hb} \%$ estimation, grouping and crossmatching and once again she was sent for the departmental USG for confirmation. But report of which was inconclusive. We went ahead with our decision for LSCS. Live thoracopagus conjoined twins, both females were delivered by breechs during LSCS with no intrapartum or postpartum complication till discharge on $4^{\text {th }}$ postoperative day.

After diagnosis by ultrasonography mother went to a couple of radiologists. Nobody was sure of exsisting pathology. But the patient did not come to the Burdwan Medical College Hospitafor confirmationl. After that patient was in dilemma whether to terminate and where to terminate the pregnancy. When the pain abdomen started she went to a local nursing home. The nursing home medical board referred the patient to any Medical College Hospital, a tertiary care centre, for better management of the mother as well as unborn preterm baby. 

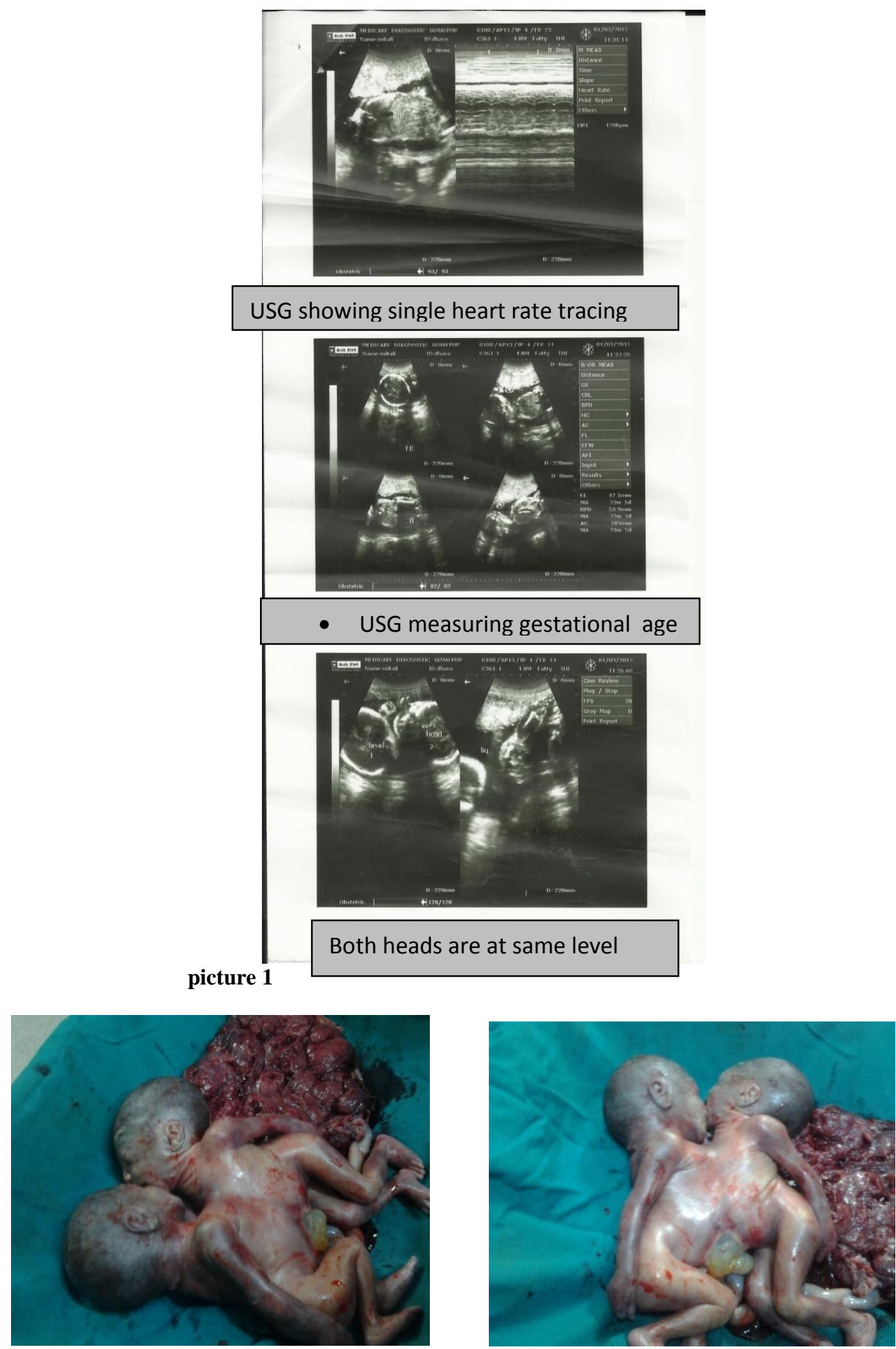

picture 2 showing thoracopagus conjoined twins

\section{Discussion}

Conjoined twins are identical twins ${ }^{1}$ whose bodies are joined in utero. Conjoined twins are also known as Siamese twins as it came from famous conjoined twins Chang and Eng Bunker(1811-1874), born in Siam, Thiland $^{2}$. Conjoined twins is a rare phenomenon. The occurrence is estimated to range from once in every 50,000 to 200,000 births $^{3}$. In our hospital the incidence is 1 in 278000 births. Most of conjoined twins(70\%) are female $^{4}$ which was corresponded our finding. Approximately 40 to 60 percent of conjoined twins are born alive, 
and about 35 percent survive only one day. The overall survival rate for conjoined twins is $25 \%$. One of the most common type thoracopagus twins, makes up about 40 percent of all conjoined cases. These twins are connected at the upper portion of the torso and share heart. Two contradictory theories explain the development of conjoined twins. The older theory is fission, in which the fertilized egg splits partially. The second and more generally accepted theory is fusion, in which the fertilized eggs completely separated but stem cell find likestem cell on the other twin and fuse the twins together. Being monozygotic conjoined twins have single chorion and single amnion like some monozygotic non-conjoined twins which also share these structures in utero ${ }^{6}$. Separation of conjoined twins is very difficult as majority share viscera and blood vessels. Diagnosis of conjoined twins is as difficult as its separation especially in the rural areas.

\section{References}

[1] "Conjoined Twins Facts". University of Maryland Medical Center. Retrieved 6 January 2012.

[2] "Conjoined Twins". University of Maryland Medical Center. January 8, 2010.

[3] Hanson JW. Incidence of conjoined twinning. Lancet. 1975;2:1257.

[4] Edmonds LD, Layde PM. Conjoined twins in the United States, 1970-1977. Teratology. 1982;25:301-8.

[5] James L. Stone and James T. Goodrih. The craniopagus malformation: classification and implications for surgical separation. Brain 2006 129(5):1084-1095.

[6] Le, Tao; Bhushan, Vikas; Vasan, Neil (2010). First Aid for the USMLE Step 1: 2010 20th Anniversary Edition. USA: The McGraw-Hill Companies, Inc. p. 121. ISBN 978-0-07-163340-6. 